\title{
Effect of Microorganisms in the Bioremediation of Spent Engine Oil and Petroleum Related Environmental Pollution
}

\section{${ }^{1 *}$ ADELEYE, AO; ${ }^{2}$ NKEREUWEM, ME; ${ }^{1}$ OMOKHUDU, GI; ${ }^{1}$ AMOO, AO; ${ }^{3}$ SHIAKA, GP; ${ }^{3}$ YERIMA, MB}

\author{
${ }^{I}$ Department of Environmental Sciences, Faculty of Science, ${ }^{2}$ Department of Soil Science, Faculty of Agriculture, ${ }^{3}$ Department of \\ Microbiology and Biotechnology, Faculty of Science, Federal University Dutse, Nigeria. \\ *Corresponding author Email: adeniyi.adeleye@fud.edu.ng Telephone: +2348162784457
}

\begin{abstract}
The technological developments currently witnessed in the world regarding the utilization of hydrocarbon related products have increasingly brought about all forms of hydrocarbon related environmental pollution. This current review documents the influence of hydrocarbon utilizing microorganisms in bringing about biodegradation of spent engine oil and other petroleum related environmental pollution. Hydrocarbonoclastic bacteria and fungi when given optimum environmental conditions and nutritional requirements have been documented to bring about effective bioremediation of oil polluted environments. This review has compiled the monumental influence of hydrocarbonoclastic microorganisms most especially bacteria and fungi in aiding bioremediation of spent engine oil and other petroleum related environmental pollution. Pseudomonas alcaligenes LR14 (59\%), Klebsiella aerogenes CR21 (62\%), Klebsiella pneumonia CR23 (58\%), Bacillus coagulans CR31 (45\%) and Pseudomonas putrefacience CR33 (68\%) reportedly exhibited spent engine oil polluted soil degradation rate while Fungi like Aspergillus, Cephalosporium and Pencillium species were also found to be the potential microorganisms responsible for hydrocarbon bioremediation. This current review, equally documents the environmental and nutritional requirements needed by these hydrocarbon oxidizers to accomplish the desired bioremediation process.
\end{abstract}

DOI: https://dx.doi.org/10.4314/jasem.v22i2.1

Copyright: Copyright $\left({ }^{\circ} 2018\right.$ Adeleye et al. This is an open access article distributed under the Creative Commons Attribution License (CCL), which permits unrestricted use, distribution, and reproduction in any medium, provided the original work is properly cited

Dates: First received 14 December 2017; Received in revised form 15 January 2018; Accepted 10 February 2018

Keywords: Bioremediation, spent engine oil, hydrocarbon oxidizers, environmental pollution

The dependence on petroleum products for energy sources in the world over has increasingly led to the pollution of the terrestrial and aquatic ecosystems. Kvenvolden and Cooper (2003) described petroleum based products as key sources of energy that daily life of humans and industries depend upon and are predominantly gotten from crude oil which is naturally occurring in a liquid state but with multifarious mixture of organic molecules that are mostly hydrocarbons of varied chemical and physical attributes.

Spent engine oil which is the focus of this review is derived subsequent to being used and dispensed off from lubricating various internal combustion engines that include all categories of motor vehicles. Engine oil is described by Klamann (1984) as the oil that principally functions as cleaning the motor engines, lubricating the moving parts of motor engines, inhibiting corrosion of motor engines, improving sealing and cooling the engine by transporting heat away from the moving parts. The present day engine oils are derivative of petroleum-based and non-petroleum produced chemical compounds. Engine oils are, therefore, mainly blended by employing base oils composed of hydrocarbons (organic compounds containing carbon and hydrogen exclusively), for instance mineral oil (Corsico et al., 1999).
Idemudia et al. (2014) reported the pollution of the soil by petroleum products as a huge environmental concern worldwide. The chemical and concentration of the pollutants, geological, physical and biological attributes of the polluted site play important role in the persistence of petroleum products in soil. Microorganisms utilizing the petroleum hydrocarbons in the soil depend hugely on the interaction of these factors as suitable conditions are provided (Rahman et al., 2002a). This implies that the fate of petroleum products found in soil depends solely on the soil microbial community, as degradation cannot take place without these hydrocarbonoclastic microorganisms. It has been well established in the literature that microorganisms are entirely dependent on the availability of nutrients for survival. The growth rate of oil degrading bacteria on contaminated soils is often restricted by the accessibility of nutrients like nitrogen and phosphorus (Pritchard and Costa, 1991; Bragg et al., 1993; Lee et al., 1993; Venosa et al., 1996). These nutrients are the basic building blocks of life and create the enabling environment for necessary enzymes produced by the microorganisms to break down hydrocarbon compounds.

Biodegradation of oil utilizes natural microbial activities as well as the enzymatic prowess of native hydrocarbondegrading microbial community and modifying environmental factors needed for optimum microbial 
growth (Atlas, 1981). According to Prince (2002), several physicochemical methods have been employed to clean up the oil residues but in comparison to physicochemical methods, biological method such as biodegradation is noninvasive, simple to maintain, can be applied over large areas and it is a comparatively cost effective method for the treatment of oil pollution due to the fact that the bulk of molecules in the crude oil and refined products can be biodegraded and oil-degrading microorganisms are naturally ubiquitous (Chaîneau et al., 2005; Joo et al., 2008).

The capability of microorganisms to degrade petroleum products in the soil has been extensively reported by several authors (Kastner, 2001; Okerentugba and Ezeronye, 2003; Okoh, 2003; Uba and Ifeanyi, 2013). However, the two major bioremediation approaches reported by Nilanjana and Preethy (2011) indicate the employment of (a) bioaugmentation in which known oil degraders in the form of microorganisms are seeded or added to assist the indigenous and existing microbial community and (b) biostimulation in which the growth of existing oil degrading microorganisms is enhanced by the addition of nutrients that may be limiting their optimum growth.

\section{ENGINE OIL COMPOSITION}

According to Butler and Mason (1997), engine oil is a complex mixture of hydrocarbons and other organic compounds, together with some organometallic components. It is used to grease automobile engine parts so as to keep everything running smoothly (Hagwell et al., 1992). The most essential attribute of engine oil for automotive use is its viscosity (Mandri and Lin, 2007). New motor oil contains a higher percentage of fresh and more volatile and water soluble hydrocarbons that would be more of a concern for acute toxicity to organisms. Most engine oils are produced from a heavier, thicker petroleum hydrocarbon base stock gotten from crude oil with additives to develop certain attributes. Typical engine oil consists of hydrocarbons having between 18 and 34 carbon atoms per molecule. Before its use, engine oil consists of a complex mixture of hydrocarbons that make up 80 to 90 percent of its volume and performance-enhancing additives that make up 10 to 20 percent of its volume (Chris, 2007).

Engine oil is transformed during use due to the breakdown of additives, contamination with the products of combustion, and the accumulation of metals like Magnesium, Copper, Zinc, Lead, Cadmium and so on from the wear and tear of the engine during the course of its running. This makes the composition of spent engine oil difficult to generalize or describe in exact chemical terms. The key components of a typical spent engine oil consist of aliphatic and aromatic hydrocarbons such as phenol, naphthalene, benzo (a) anthracene, benzo (a) pyrene, and fluoranthene (Irwin et al., 1997).

\section{PETROLEUM HYDROCARBONS}

Crude oil or petroleum is defined by Riser-Roberts (1998) as a complex substance found in deposits in the world over. Kvenvolden (2006) equally defined crude oil as a mixture of compounds in petroleum products that are all made completely from hydrogen and carbon, hence the name "hydrocarbon". This author further reiterated that the present day crude oil is formed from the conserved remains of ancient zooplankton and algae which have settled down in a sea or lake bottom in large quantities under conditions known as anoxic. The organic matter blends with mud and is concealed under heavy layers of sediment over geological time resulting in high heat and pressure. This process transforms the organic matter, first into a waxy material known as kerogen (found in numerous oil shales around the world), and then with additional heat into liquid and gaseous hydrocarbons through a process known as catagenesis (Braun and Burnham, 1993). In its natural state, this substance consists of hundreds of thousands of different hydrocarbon compounds. Huesemann and Moore (1993) reported that all chemical compounds known as hydrocarbons are made of various carbon and hydrogen atoms' arrangements but those that are made up of crude oil can be split into three major groups: saturated and unsaturated aliphatics and aromatic hydrocarbons.

Saturated hydrocarbons (also known as alkanes) have got the maximum number of hydrogen atoms possible and, therefore, have got no double bonds. Alkanes can be classified as linear, branched or cyclic in structures (RiserRoberts, 1998). Unsaturated compounds in the other hand, do not possess the full complement of hydrogen atoms, but instead have formed either one double carbon bond (alkenes), two double carbon bonds (dienes), or at least one triple carbon bond (alkynes). Aromatic hydrocarbons consist of an aromatic ring, which invariably contains six carbon atoms that are connected with three alternating double bonds (Hornback, 1998). BTEX (Benzene, Toluene, Ethylbenzene, and Xylene) compounds are examples of aromatic hydrocarbons. Frick et al. (1999) reported that aromatic molecules that have got two or more bonded aromatic rings are denoted as Polycyclic Aromatic Hydrocarbons (PAHs).

Refined petroleum products are very common to daily life as they are utilized frequently, but still remain highly complex compounds. Kerosene, for instance has as many as 10,000 different hydrocarbons (Riser-Roberts, 1998). The composition of these products however is dependent on their level of refinement they are subjected to. Diesel fuels for instance possess approximately 60 to $70 \% \mathrm{C}_{10}-\mathrm{C}_{19}$ aliphatic alkanes and cycloalkanes, with the bulk of the residual components being aromatic. Compounds including porphyrins and their derivatives that contain no hydrocarbon may equally be found in crude oil (Callot and Ocampo, 2000). Chicarelli et al. (1990) reported that metals that could be found in crude oil through their association with porphyrins include Nickel, Vanadium, Iron, Zinc, Cobalt, Titanium and Copper.

Environmental and Health Impacts of Spent Engine Oil and Petroleum Hydrocarbons: Many research studies that have been conducted on spent engine oil and petroleum hydrocarbons show that it readily renders the environment unpleasant and creates a potential threat to humans, animals and the vegetation as a whole. Oil polluted soils are of huge environmental concern due to their being unsuitable for agricultural and recreational use and are equally potential 
sources of surface and ground water pollution (Schwab et al., 1999). Many authors (Okerentugba and Ezeronye, 2003; Adelowo et al., 2006) have reported that the presence of these pollutants in the terrestrial and aquatic environments constitutes public health and socio-economic hazards. Spent engine oil has been reportedly implicated by Irwin et al. (1997) as a pollutant of concern, with large volumes entering aquatic ecosystems through water runoff created by rainfall. These authors further reiterated that the key source of petroleum pollution in urbanized estuaries emanates from spent engine oil. Fresh engine oil on the other hand, contains fresh and lighter hydrocarbons that would be more of a concern for short-term (acute) toxicity to living organisms, whereas spent engine oil has more metals and heavy polycyclic aromatic hydrocarbons (PAHs) that would add to long-term (chronic) hazards including carcinogenicity.

Aromatic hydrocarbons are reported to be the most acutely toxic components of petroleum products, and are also linked with chronic and carcinogenic effects. For example chronic effects of naphthalene, a component of spent engine oil, include changes in the liver and harmful effects on the kidneys, heart, lungs, and nervous system. Similar to numerous individual PAHs, spent engine oil has been shown to be mutagenic and teratogenic. Certain immunological, reproductive, fetotoxic, and genotoxic effects have been linked with a few of the compounds found in spent engine oil (Irwin et al., 1997).

A research conducted by the National Research Council (1985) revealed that spent engine oil is not only dangerous to human health, it equally kills an implausible amount of aquatic organisms such as fish upon absorption when spilled spent engine oil for instance finds its way into aquatic ecosystems. This author further reiterated that some toxic components of spent engine oil are persistent and can consequently accumulate in the terrestrial and aquatic ecosystems, finding their way into the food chain and applying their harmful effects higher up the food chain. Consequently spent engine oil can affect fish population by both direct toxicity and by a reduction in the benthic species on which they feed on. In the terrestrial ecosystem, the indiscriminate discharge of spent engine oil into the environment can have great negative impact on food productivity by its adverse effects on the fertility of the soil. The severity of impact would however, depend on the quantity of spent engine oil spilled. Substantial quantities of such petroleum hydrocarbons can consequently 'sterilize' the soil and stop crop growth and yield for a long period of time (Onwurah et al., 2007).

Microorganisms Involved in Oil Degradation: It has been reportedly established in the literature that no single species of microorganisms can entirely degrade any particular oil and this knowledge has been widely acknowledged by the scientific community (Balba et al., 1998a). The microbial degradation of both crude and refined oils appears to include a consortium of microorganisms, including both eukaryotes and prokaryotes. Moneke and Nwangwu (2011) have reported the ability of Pseudomonas species to reduce many types of oil under laboratory conditions while Ismail et al. (2014) confirmed Pseudomonas and Klebsiella species as being amongst the most efficient hydrocarbon degrading bacteria that are prevalent in Nigerian environment. However, the capability of these microorganisms to utilize oil has been attributed by Ijah et $a l$. (2008) to their enzymatic prowess and ability to survive harsh environmental conditions.

The commonest genera implicated for oil degradation comprise principally Nocardia, Pseudomonas, Acinetobacter, Flavobacterium, Micrococcus, Arthrobacter, Corynebacterium, Achromobacter, Rhodococcus, Alcaligenes, Mycobacterium, Bacillus, Rhodotorula, Candida and Sporobolomyces species (Atlas, 1981; Bossert and Bartha, 1984; Sarkhoh et al., 1990; Atlas and Bartha, 1992; Balba et al., 1998b).

Another set of authors (Leahy and Colwell, 1990; Hamamura et al., 2006; Chikere et al., 2009; Obayori and Salam, 2010) reported the most important hydrocarbon degraders of bacterial origin as Achromobacter, Acinetobacter, Alcaligenes, Arthrobacter, Bacillus, Burkholderia, Collimonas, Corynebacterium, Dietzia, Flavobacterium, Gordonia, Micrococcus, Mycobacterium, Nocardia, Nocardioides, Pseudomonas, Ralstonia, Rhodococcus, Sphingomonas, Variovorax and other bacterial clones that cannot be cultured. These authors went further to document Aspergillus, Candida, Cunninghamella, Fusarium, Mucor, Penicillium, Phanerochaete, Rhodotorula, Sporobolomyces and Trichoderma as Fungi that have got the ability to expunge hydrocarbon related pollutants from the soil.

Bacteria have got efficient systems that aid the synthesis of enzymes that can readily attack hydrocarbon pollutants in their immediate environment. According to Ismail et al. (2014) five bacterial isolates grew abundantly in spent engine oil polluted soil samples coupled with showing high optical density in oil broth having incubated for 7 days. These authors reiterated further that the spent oil polluted soil degradation rate exhibited by Pseudomonas alcaligenes LR14, Klebsiella aerogenes CR21, Klebsiella pneumonia CR23, Bacillus coagulans CR31, and Pseudomonas putrefacience CR33 were 59\%, 62\%, 58\%, $45 \%$ and $68 \%$ of the oil respectively after a 21 day incubation period.

Several indigenous microorganisms have been reported by Dhaker and Jain (2011); Jain et al. (2011a) as having the capability of degrading petroleum hydrocarbon pollutants in water and soil. According to Prince (2005), there are more than seventy five (75) dependably described genera of bacteria that can degrade oil and other hydrocarbons that may be present in different environmental media. Specifically, many researchers (Bouchez-Naitali et al., 1999; Macnaughton et al., 1999; Williams et al., 1999; Odokuma and Dickson 2003; Siciliano et al., 2003; Zucchi et al., 2003; Chaillan et al., 2004; Evans et al., 2004; Nweke and Okpokwasili, 2004; Kaplan and Kitts, 2004; Alquati et al., 2005; Ebuehi et al., 2005; Vinas et al., 2005; Ayotamuno et al., 2006; Hamamura et al., 2006; Maila et al., 2006; Adoki and Orugbani 2007; Rojas-Avelizapa et 
al., 2007; Wolicka et al., 2009), have reported the isolation of many hydrocarbon degrading microorganisms from soils polluted by hydrocarbons.

Ajisebutu and Alofe (2001), listed over 100 species of bacteria have been reportedly implicated in having the capability of utilizing hydrocarbons as their source of energy. The rapid disappearance of crude oil spills from the ground in oil fields, oceans, seas and beaches has been pinpointed by many researchers as the evidence in support of hydrocarbon utilization by these microorganisms. The most prominent among the implicated bacteria are Pseudomonas, Acromonas, Acromobacter, Alcaligenes, Nocardia and Mycobacterium (Ajisebutu, 1984).

Yeasts and some species of Candida have equally been reported to expunge some hydrocarbon compounds. The yeast species, namely, Candida lipolytica, Rhodotorula mucilaginosa, Geotrichum sp, and Trichosporon mucoides that were isolated from polluted water were known to have actively taken part in the degradation of petroleum compounds (Bogusławska-Was and Da browski, 2001). Hobbs (1995) equally reported the productive participation of many genera of fungi in bioremediation exercise. Fungal genera, namely, Amorphoteca, Talaromyces, Neosartorya and Graphium and yeast genera, namely, Candida, Yarrowia, and Pichia were isolated from petroleum polluted soil and demonstrated to be the potential microorganisms responsible for hydrocarbon degradation (Chaillan et al., 2004). Singh (2006) also identified a group of terrestrial fungi, namely, Aspergillus, Cephalosporium, and Pencillium species which were also found to be the potential microorganisms responsible for crude oil hydrocarbon remediation.

Bacterial genera, namely, Gordonia, Brevibacterium, Aeromicrobium, Dietzia, Burkholderia, and Mycobacterium isolated from petroleum polluted soil proved to be the potential microorganisms accountable for hydrocarbon degradation (Chaillan, et al., 2004). The degradation of polyaromatic hydrocarbons by Sphingomonas sp was equally reported by Daugulis and McCracken (2003). In a bioremediation of spent oil polluted soil study conducted and reported by Adams et al. (2014), heterotrophic bacteria that were isolated and identified include; Arthobacter, Enterobacter, Micrococcus, Pseudomonas, Klebsiella, E. coli and Corynebacterium coupled with fungal species including; Aspergillus sp., Trichoderma, Penicillum and Mucor.

The dependable contribution of a given density of oildegrading microorganisms to the removal of oil depends largely on their characteristic metabolic capability. Singer and Finnerty (1984) reported that of the numerous petroleum fractions, shorter alkanes of intermediate length $\left(\mathrm{C}_{10}-\mathrm{C}_{20}\right)$ are the most desired substrates and tend to be most readily degradable when compared with branched chain alkanes which are degraded more slowly than the corresponding normal alkanes. Bartha (1986) reiterated that longer chain alkanes known as waxes $\left(\mathrm{C}_{20}-\mathrm{C}_{40}\right)$ are hydrophobic solids and as a result are difficult to degrade due to their poor bioavailability and water solubility. It has been widely reported that hydrocarbons polluting the environment can be predominantly biodegraded by microbial community consisting of bacteria, fungi and yeast.

Monitoring of Microbial Degradation of Oil: Degradation of spent oil or hydrocarbon pollutants in the aquatic and terrestrial environments using microorganisms is often directly or indirectly associated with the metabolic activities of the degrading microorganisms present and is commonly linked with some changes which provide beneficial information on the degree of biodegradation. However, biodegradation can be estimated or monitored in a number of ways. The activity of aerobic microorganisms for example, can be measured by the amount of oxygen they readily consume, or the amount of carbon dioxide they produce. Biodegradation by anaerobic microbes can as well be estimated or monitored by the amount of methane that they may be able to produce (Diaz, 2008). According to Kwaspisz et al. (2008), biodegradation can be measured or monitored in terms of nutrient most particularly nitrogen and phosphorus uptake by microorganisms involved in such degradation. Other parameters that commonly employed in monitoring the biodegradation of spent oil include $\mathrm{pH}$, temperature, total petroleum hydrocarbon (TPH), as well as the microbial population density of microorganisms that are actively taking part in such degradation at any point in time.

Oxygen uptake: Aerobic microorganisms are expected to utilize oxygen in the course of spent engine oil degradation. Oxygen uptake measurement is regarded as a simple method which provides a rapid estimate of microbial activity for samples containing large amounts of microorganisms and this can be done using Winkler titration or with a suitable respirometer or oxygen electrode. It has been reported by National Research Council (1985) that oxygen uptake usually increases with increasing microbial activity and vice versa.

Evolution of Carbon dioxide: Measurement of $\mathrm{CO}_{2}$ evolution has been reported by the National Research Council (1985) as a simple method that provides a rapid estimate of the activity of samples containing large numbers of microorganisms. $\mathrm{CO}_{2}$ can be simply measured by the titration of $\mathrm{BaCO}_{3}$ or by adopting infrared gas analysis. Carbon dioxide evolution measurement as a means of monitoring the degradation of spent oil polluted soil would as it stands not be far from precision as microorganisms in their mission to survive are capable of utilizing these hydrocarbon pollutants as their sole source of carbon and energy thereby, converting them into less harmful products that are mostly carbon dioxide and water. The use of oxygen uptake and carbon dioxide evolution for the estimation of short term activity creates the problem of determining effects of oil or oil degradation products on endogenous respiration (National Research Council, 1985). This author went further to report that each of the methods employed in determining microbial activity is very much dependent upon the experimental conditions employed 
including the type of oil and the physical state of the oil that is being degraded.

Temperature: Temperature as a parameter readily dictates the rate of degradation of a pollutant coupled with the composition of the microbial community undertaking the microbial degradation. According to Balba et al. (1998a), no single species of microorganisms can completely degrade any particular oil, so also it implies that no single temperature can support the metabolism of all microorganisms. Optimum temperature ranges that favour metabolic activities of numerous species of microorganisms in a consortium would increase the degradation rate of pollutants. Low temperatures that are below the optimum range required for individual species of microorganisms in a consortium will unfavorably affect microbial growth and propagation by impeding enzymatic activities thereby decreasing the rate of degradation. Leahy and Colwell (1990) reported that at temperatures above the optimum range, enzymatic activities are probably going to be impeded as a result of protein denaturation.

$p H: \mathrm{pH}$ just like temperature also plays a role in the determination of the ability of microorganisms to grow or flourish in a particular environment. Most usually, microorganisms particularly bacteria grow optimally within a narrow $\mathrm{pH}$ range of between 6.7 and 7.5. Metabolic activities of microorganisms in a system can often be directly connected to the $\mathrm{pH}$ (acidity or alkalinity) of the system that is under examination. Several research studies have shown that microorganisms have got the capability of changing the $\mathrm{pH}$ of their environment through the production of metabolic waste products that can be either acidic or basic. Organic acids produced as a result of microbial activities function to aid lowering the $\mathrm{pH}$ of the system, making it more acidic unlike organic bases that would boost the $\mathrm{pH}$ of the system to make it alkaline in the process. Anaerobic processes as a result of fermentative activities would typically help lower the $\mathrm{pH}$ of the system. Subject to the nature of the metabolic waste product, the $\mathrm{pH}$ of the system would either increase or drop in correlation to microbial activity and numbers involved. Fluctuation in the $\mathrm{pH}$ of a system would consequently give an indication of the possible utilization of pollutants of concern by the microorganisms present therein (Prescott et al., 2002).

Microbial population density: The growth of microorganisms in any system is expected to follow the phases of the microbial growth curve described by Olutiota et al. (1997) namely; the lag, exponential or log, stationary and death phases. Microorganisms upon the uptake of any pollutants would normally increase in number which is an indication that the microorganisms are successfully degrading or utilizing the pollutant of concern. According to Prescott et al. (2002), reduced or stagnated microbial numbers generally give clear indication that pollutant of concern is not utilized by the microorganism present which possibly could be as a result of the presence of unfavourable or inhibiting factors in the system.
Total Petroleum Hydrocarbon (TPH): Total Petroleum Hydrocarbon (TPH) can equally be referred to as hydrocarbon oil, mineral oil, extractable hydrocarbons, or oil and grease. Basically, there are many analytical techniques available for the measurement of TPH concentrations in the environment. It is imperative to note that no single method can measure the entire range of petroleum-derived hydrocarbons. This is due to the fact that the techniques tend to vary in the way hydrocarbons are removed, cleaned up, and detected as each technique measures slightly different subsets of the petroleumderived hydrocarbons present in a given sample. Chemical composition of petroleum products is multifaceted and has got the tendency to change over time when released into the environment. It has been established that there is no method that stands to be the best for measuring all types of petroleum pollution owing to the complexity of petroleum and petroleum-derived products. The afore-stipulated factors often make it difficult to select the most appropriate analytical method for evaluating environmental samples containing hydrocarbons.

Conductivity: Conductivity is a measure of the ability of electrical current to pass through water. Conductivity in water is influenced by the presence of inorganic dissolved solids such as chloride, nitrate, sulfate, and phosphate anions or sodium, magnesium, calcium, iron, and aluminum cations. Organic compounds like oil, phenol, alcohol, and sugar have got a low conductivity when present in water. Conductivity is also affected by temperature as the warmer the water becomes, the higher the conductivity that would be recorded. Significant changes in conductivity could, therefore, be an indicator that a discharge or some other source of pollution has entered a system. Conductivity is also directly related to salinity in that conductivity increases with salinity. Aquatic organisms including microorganisms are adapted for a certain range of salinity. According to APHA (1992) and Hach Company (1992), outside of this range, microorganisms will be affected negatively and may die as some can handle high salinity, but not low salinity and others low salinity, but not high salinity.

Factors affecting Biodegradation of Spent Engine Oil and Petroleum Hydrocarbons: Abiotic factors that influence the biodegradation of oil largely determine the fate of petroleum hydrocarbons in the environment. Naturally, factors that influence the rate of microbial growth and enzymatic activities invariably affect the rate of biodegradation of petroleum hydrocarbons (Leahy and Colwell, 1990). According to these authors, the persistence of petroleum pollutants in the environment depends on the quantity and quality of the hydrocarbon mixture and also on the attributes of the affected ecosystem. An ecosystem can tolerate the indefinite persistence of petroleum hydrocarbons, whereas under alternative set of conditions the same petroleum hydrocarbons can undergo complete biodegradation within few hours or days (Leahy and Colwell, 1990). The factors that can readily influence the microbial degradation of oil include the following; 
Structure and physical state of the oil pollutant: The structure and physical state of petroleum hydrocarbons have been reported to have got significant effect on their rate of biodegradation. It has been established by Desai and Vyas (2006) that the vulnerability of hydrocarbons to undergo biodegradation is determined by its structure and molecular weight. Atlas (1981) reported that in aquatic systems, the oil usually extends thereby creating a thin slick. Due to the action of wind and wave, oil-in-water or water-in-oil emulsions may be formed. Dispersion of hydrocarbons in the water column in the form of oil-inwater emulsions ultimately increases the surface area of the oil and thereby, making it available for microbial degradation. However, large masses of mousse establish unfavourable low surface-to-volume ratios, thereby inhibiting biodegradation. According to Leahy and Colwell (1990), the formation of emulsions through the production and subsequent release of biosurfactants is an essential process in the uptake of hydrocarbons by bacteria and fungi. The degree of dispersion is abridged at low temperatures due to the viscosity of the oil (Atlas, 1981).

The main dissimilarities between oil biodegradation in soil and aquatic ecosystems following an oil spill are connected to the movement and distribution of the oil and the presence of particulate matter, each of which affects the physical and chemical nature of the oil and hence its susceptibility to microbial degradation. In the terrestrial ecosystem, oil spills are characterized primarily by vertical movement of the oil into the soil, rather than the horizontal dispersion related to the formation of slick (Bossert and Bartha., 1984; Leahy and Colwell, 1990). The bioavailability of hydrocarbons which is principally a function of concentration and physical state, sorption onto soil particles, hydrophobicity, volatilization and solubility of hydrocarbon molecules significantly affects the magnitude of biodegradation (Desai and Vyas, 2006).

Hydrocarbons vary in their vulnerability to microbial degradation and in the past, have generally been classified in the following order of decreasing vulnerability: n-alkanes $>$ branched alkanes $>$ lowmolecular-weight aromatics $>$ cyclic alkanes (Leahy and Colwell, 1990). Biodegradation rates have been demonstrated to be highest for saturates, followed by the light aromatics, with high-molecular weight aromatics and polar compounds exhibiting extremely low rates of microbial degradation (Desai and Vyas, 2006). These fractions have previously been considered relatively recalcitrant to biodegradation. Their microbial degradation however, can be attributed to co-oxidation, in which non-growth hydrocarbons are oxidized in the presence of hydrocarbons which can serve as growth substrates. Compositional heterogeneity among different crude oils and refined products influences the overall rate of biodegradation both of the oil and of its component fractions (Leahy and Colwell, 1990).

Concentration of the oil pollutant: According to Leahy and Colwell (1990), the rates of uptake and mineralization of many organic compounds by microbial populations present in the aquatic environment are largely proportional to the concentration of the compound itself. High concentrations of hydrocarbons can be linked with heavy, undispersed oil slicks in water, causing inhibition of biodegradation by nutrient or oxygen limitation or through toxic effects exerted by volatile hydrocarbons. There is the possibility that if the concentration of oil is high, negative effects on biodegradation rates following oil spills in quiescent, low-energy environments such as beaches, harbours, and small lakes or ponds, in which the oil is relatively protected from dispersion by wind and wave action would be experienced (Leahy and Colwell, 1990).

Temperature: Temperature has influence on the microbial degradation of oil owing to its effect on the physical nature and chemical composition of the oil, composition of the microbial community and rate of hydrocarbon metabolism by microorganisms (Leahy and Colwell, 1990; Atlas, 1981; Desai and Vyas, 2006). The viscosity of the oil increases at low temperature, the volatilization of toxic short-chain alkanes is reduced, and their water solubility is decreased, thereby delaying the onset of biodegradation process. Microbial degradation rates are generally detected to decrease with decreasing temperature which is believed by Leahy and Colwell (1990) to be as a result of decreased rates of enzymatic activity as such decreased temperature. These authors further reiterated that higher temperatures inevitably increase the rates of hydrocarbon metabolism to a maximum range of $30^{\circ} \mathrm{C}-40^{\circ} \mathrm{C}$ in a typical soil environment. According to Atlas (1981), even though the microbial degradation of petroleum hydrocarbon has been detected to occur as low as below $0^{\circ} \mathrm{C}$ to as high as $70^{\circ} \mathrm{C}$, it has always stood out as an essential factor influencing biodegradation rate. The influence of temperature is so paramount due to the fact that at low temperatures, the hydrocarbon molecules react sluggishly and collision experienced at this pace hardly brings about a reaction (Atlas, 1984). Bossert and Bartha (1984) reported a temperature range of $20^{\circ} \mathrm{C}-30^{\circ} \mathrm{C}$ in freshwater environments and $15^{\circ} \mathrm{C}-20^{\circ} \mathrm{C}$ in marine environments above which the membrane toxicity of hydrocarbons is amplified with respect to their environments.

$p H$ : According to Desai and Vyas (2006), $\mathrm{pH}$ is not of significant importance in marine environments owing to the fact that it is well buffered at about $\mathrm{pH} 8.5$, but soil $\mathrm{pH}$ differs extensively and $\mathrm{pH}$ range of 7 to 8 has been reportedly detected to support optimum microbial degradation in such environment. Leahy and Colwell (1990) reported that extremity in $\mathrm{pH}$ in some environments inevitably result to a negative influence on the ability of microbial populations to degrade hydrocarbon compounds present therein.

Oxygen: It has been widely reported that biodegradation of hydrocarbon is a typical aerobic process. However, anaerobic biodegradation of hydrocarbons has equally been reported. The proof supporting anaerobic degradation of hydrocarbons is not significant due to the fact that the rate is considered insignificant (Atlas, 1981; US Congress, 1991). Desai and Vyas (2006) reported that in the absence of molecular oxygen, nitrate, iron, bicarbonate, nitrous oxide and sulfate, have demonstrated acting as an alternate 
electron acceptor during microbial degradation of hydrocarbons. According to Bragg et al. (1992), the infusion of oxygen will catalyze bacterial enzymes into the hydrocarbon leading to cellular metabolism. The preliminary steps involved in the catabolism of aliphatic, cyclic, and aromatic hydrocarbons by hydrocarbonoclastic microorganisms involve the action of the enzyme known as oxygenases which requires molecular oxygen. Aerobic conditions are thus required for this route of microbial oxidation of hydrocarbons in the environment. Oxygen limitation conditions usually do not exist in the upper levels of the water column in aquatic environments. Nevertheless, aquatic sediments are usually anoxic with an exception of a thin layer at the surface of the sediment (Leahy and Colwell, 1990).

Nutrients: Microorganisms inevitably require nutrients for survival in their environment (Atlas, 1984). They undergo oil degradation with a view to acquiring energy and the building blocks for their biomass. It is important to point out that hydrocarbonoclastic microorganisms can readily utilize both organic and inorganic nutrients in accomplishing microbial degradation of oil pollutants. Preferably, the utilization of organic nutrients tagged as waste products that are cheap, readily available and ecofriendly can be adopted as biostimulants in accomplishing bioremediation process (Adeleye et al., 2017). However, microorganisms would also require essential nutrients as hydrocarbons contain hydrogen $(\mathrm{H})$ and carbon $(\mathrm{C})$ as their sole elements. Microorganisms have got varying nutritional requirements but basically all of them require Nitrogen (N), Phosphorus (P) and some trace elements in addition to the carbon source (Atlas, 1984). The macronutrients in Nitrogen and Phosphorus are particularly essential to ensure fast and complete degradation of the oil (Braddock et al., 1997). It is very important that the nutrients needed for microbial metabolism are supplied in the right ratio(s) so as to ensure optimal growth conditions for the microorganisms present in such environment. Alexander et al. (1982) reported that a C: N: P ratio of 100:10:2 was enough to ensure optimal growth of microorganisms. The nutrient concentration should be maintained at a level high enough to support maximum oil biodegradation based on the kinetics of nutrient consumption as higher concentrations of nutrients would provide no added benefit but may lead to potentially detrimental ecological and toxicological impacts (Zhu et al., 2001). Therefore, nutrients most particularly nitrogen, phosphorus, and in some cases iron are very significant components for staging successful biodegradation experiments. However, some of these nutrients in surplus or limited amounts could become limiting factors, therefore, affecting the process of biodegradation (Zhu et $a l .$, 2001; Nilanjana and Preethy, 2010).

Water: Water is required by microorganisms for growth since it makes up a huge proportion of their cell cytoplasm. Most enzymatic reactions do take place in solution with water as the basic solvent. According to Atlas and Bartha (1998), water is required for the transport of most materials in and out of the cell. The water activity or water potential (aw) of a typical soil for example, can range from 0.00 to
0.99 , in contrast to aquatic environments, in which water potential is stable at a value near 0.98 (Bossert and Bartha., 1984; Leahy and Colwell, 1990). Hydrocarbon biodegradation in terrestrial ecosystems for instance may, therefore, be limited by the available water required for microbial growth and metabolism (Leahy and Colwell, 1990).

Other variables: Many variables such as pressure and salinity have also been reported to have got significant effects on the rate of microbial oil degradation (US Congress, 1991). The author further reiterated that the variables are not a key problem in a natural environment that has indigenous microbial population. It has equally been reported by Maki et al. (2005) that photo-oxidation increases the biodegradation of oil or petroleum hydrocarbons by increasing the bioavailability of the oil and thus enhancing microbial activities.

Conclusion: Hydrocarbon related pollution has been established to be antagonistic to the ecosystem balance and health of various environments they are linked with. Therefore, the need to adopt eco-friendly approaches in the remediation and reclamation of spent engine oil and other petroleum hydrocarbon polluted environments should be of paramount interest these days. It can be concluded from this current review that oil degrading microorganisms have got the ability to bring about the bioremediation of spent engine oil and other petroleum hydrocarbon polluted environments provided that favourable environmental and nutritional conditions are ensured in bringing about their optimal growth. The fact that bioremediation technologies have been recognized and reported over the years by scientists as suitable tools meant for the restoration of hydrocarbon polluted environments, calls for modern day innovative ideas that will further enhance its appropriateness. Again, as reported in this review, bioremediation technologies have got huge potentials in ensuring effective cleanup of spent engine oil and other petroleum hydrocarbon polluted environments. However, efforts should be geared towards researching into appropriate techniques that will inevitably facilitate the adoption of these technologies in the restoration of hydrocarbon related polluted environments the more.

\section{REFERENCES}

Adams, GO; Tawari-Fufeyin, P; Igelenyah, E (2014). Bioremediation of Spent Oil Contaminated Soils Using Poultry Litter. Res. J. Engineer. Appl. Sci. 3(2): 124-130.

Adeleye, AO; Yerima, MB; Nkereuwem, ME; Onokebhagbe, VO (2017). Biostimulatory Effects of Organic Nutrients on Spent Engine Oil and Hydrocarbon Related Soil Pollution: A Review. Inter. J. Appl. Res.Technol. 6(7): 52-60.

Adelowo, OO; Alagbe, SO; Ayandele, AA (2006). TimeDependent Stability of Used Engine Oil Degradation by Cultures of Pseudomonas fragi and Achromobacter aerogenes. Afr. J. Biotechnol. 5 (24): 2476-2479. 
Adoki, A; Orugbani, T (2007). Removal of Crude Petroleum Hydrocarbons by Heterotrophic Bacteria in Soils Amended with Nitrogenous Fertilizer Plant Effluents. Afr. J. Biotechnol. 6: 1529-1535.

Ajisebutu, SO (1984). Structural and Physiological Changes Induced by Crude Oil Hydrocarbons in Some Species of Marine Bacteria. PhD Thesis. Available at https://link.springer.com/article/10.1007/BF00694313. (Accessed on 6th November, 2017).

Ajisebutu, SO; Alofe, FV (2001). The Biotechnology of Oil Spillage Treatment: Bioremediation. Science Research Annals. 1 (1): 54-60.

Alexander, SK; Schropp, SJ; Schwarz, JR (1982). Spatial and Seasonal Distribution of Hydrocarbon-Utilizing Bacteria of Sediment from the Northwestern Gulf of Mexico. Contrib. Mar. Sci. 25: 13-19.

Alquati, C; Papacchini, M; Riccardi, C; Spicaglia, S; Bestetti, G (2005). Diversity of NaphthaleneDegrading Bacteria from a Petroleum Contaminated Soil. Annal. Microbiol. 55: 237-242.

American Public Health Association (APHA) (1992). Standard Methods for the Examination of Water and Wastewater. 18th Edition. Washington, DC.

Atlas, RM (1981). Biological Degradation of Petroleum Hydrocarbons: An Environmental Perspective. Microbiol. Rev. 45: 180-209.

Atlas, RM (1981). Biological Degradation of Petroleum Hydrocarbons: An Environmental Perspective. Microbiol. Rev. 45: 180-209.

Atlas, RM; Bartha, R (1998). Microbial Ecology: Fundamentals and Applications. Benjamin / Cummings Publishing Company. p. 281-324.

Atlas, RM; Bartha, R (1981). Microbial Ecology: Fundamentals and Applications. Reading, Ma: Addison-Wesley Publishing Company.

Atlas, RM; Bartha, R (1992). Hydrocarbon Biodegradation and Oil-Spill Bioremediation. In: Marshall, K.C. (Ed.), Advances in Microbial Ecology. Vol. 12, Plenum Press, New York, p. 287-338.

Ayotamuno, MJ; Kogbara, RB; Ogaji, SOT; Pobert, SD (2006). Bioremediation of a Crude Oil Polluted Agricultural Soil in Port Harcourt Nigeria. Appl Energy. 83: 1249-1257.

Balba, MT; Al-Daher, R; Al-Awadhi, N; Chino, H; Tsuji, $\mathrm{H}$ (1998a). Bioremediation of Oil-Contaminated Desert Soil: The Kuwaiti Experience. Environment Institute. 24 (1/2): 163-173.
Balba, MT; Al-Awadhi, N; Al-Daher, R (1998b). Bioremediation of Oil-Contaminated Soil: Microbiological Methods for Feasibility Assessment and Field Evaluation. J. Microbiol. Methds. 32: 155164.

Bartha, R (1986). Biotechnology of Petroleum Pollutant Biodegradation. Microbiol. Ecol., 12: 155-172.

Bogusławska-Was, E; Da browski, W (2001). The Seasonal Variability of Yeasts and Yeast-like Organisms in Water and Bottom Sediment of the Szczecin Lagoon. Inter.J. Hygiene Environ. Health. 203 (5-6): 451-458.

Bossert, I; Bartha, R (1984). The Fate of Petroleum on Soil Ecosystems. Petroleum Microbiology. R. M. Atlas. MacMillan: New York, p. 435-473.

Bouchez-Naitali, M; Rakatozafy, H; Marchals, R; Leveau, JV; Vandecasteele, JP (1999). Diversity of Bacterial Strains Degrading Hexadecane In Relation To The Mode Of Substrate Uptake. J Appl. Microbiol. 86: 421-428.

Braddock, JF; Ruth, ML; Catterall, PH (1997). Enhancement and Inhibition of Microbial Activity in Hydrocarbon-Contaminated Arctic Soils: Implications for Nutrient- Amended Bioremediation. Environmental Science and Technology. 31: 20782084.

Bragg, JR; Prince, RC; Harner, EJ; Atlas, RM (1993). Bioremediation Effectiveness Following the Exxon Valdez Spill. In: Proceedings of the 1993 Oil Spill Conference (Prevention, Preparedness and Response). American Petroleum Institute, Washington, D.C, p. 435-446.

Bragg, JR; Prince, RC; Wilkinson, JB; Atlas, RM (1992). Bioremediation for Shoreline Cleanup Following the 1989 Alaskan Oil Spill. Houston, TX: Exxon Co.

Braun, RL; Burnham, IK (1993). Chemical Reaction Model for Oil and Gas Generation from Type I and Type II Kerogen. Lawrence Livermore National Laboratory. Available at http://www.osti.gov/bridge/servlets/ purl/10169154-cT5xip/10169154.PDF. (Accessed on February 29, 2017.)

Butler, CS; Mason, JR (1997). Structure-Function Analysis of the Bacterial Aromatic Ring-Hydroxylating Dioxygenases. Adv. Micro. Physiol. 38: 47-84.

Callot, HJ; Ocampo, R (2000). Geochemistry of Porphyrins. In: Kadish K. M, Smith, K. M. and Guilard, B. (Eds.) The Porhpyrin Handbook Vol. 1, Academic, San Diego, C.A USA. p. 349-398.

Chaillan, F; Le Fleche, A; Bury, E; Phantavong, Y; Grimont, P; Saliot, A; Oudot, J (2004). Identification and Biodegradation Potential of Tropical Aerobic 
Hydrocarbon-Degrading Microbiol. 155: 587-595.

Chaîneau, H; Rougeux, G; Yéprémian, C; Oudot, J (2005). Effects of Nutrient Concentration on the Biodegradation of Crude Oil and Associated Microbial Populations in the Soil. Soil Biol. Biochem. 37: 14901497.

Chicarelli, MI; Eckardt, CB; Owenn, CR; Maxwell, JR; Eglington, G; Hutton, RC; Eaton, AN (1990). Application of Inductivity Coupled Plasma Mass Spectrometry in the Determination of Organometallic Compounds in Chromatographic Fractions from Organic Rich Shales. Organ. Geochem. 15: 26-274.

Chikere, CB; Okpokwasili, GC; Chikere, BO (2009). Bacterial Diversity in a Tropical Crude Oil Polluted Soil Undergoing Bioremediation. Afr. J Biotech. 8: 2535-2540.

Chris, C (2007). Implementing Phytoremediation of Petroleum Hydrocarbons, Methods in Biotechnology, 23: 99-108. Humana Press. ISBN 1588295419.

Corsico, G; Mattei, L; Roselli, A; Gommellini C (1999). Poly (internal olefins) - Synthetic Lubricants and High-Performance Functional Fluids. Marcel Dekker, Chapter 2, p. 53-62, ISBN 0-8247-0194-1.

Daugulis, A; McCracken, CM (2003). Microbial Degradation of High and Low Molecular Weight Polyaromatic Hydrocarbons in a Two-Phase Partitioning Bioreactor by Two Strains of Sphingomonas sp. Biotechnology Letters. 25(17): 1441-4.

Desai, A; Vyas, P (2006). Applied Microbiology. Petroleum and Hydrocarbon Microbiology. Department of Microbiology. M.s.University of Baroda .Vadodara 390 002. 13-Apr-2006 (Revised 6Dec-2006). p. 1-22

Dhaker, AK; Jain, PK (2011). Sewage Pollutants and their Bioremediation by Using Different Microorganism. In: Recent Advances in Environmental Biotechnology, Jain P.K., Gupta V.K. and Bajpai V. (Eds.). LAP Lambert Academic Publishing AG and Co. KG, Germany, p. 189-204.

Ebuehi, OAT; Abibo, IB; Shekwolo, PD; Iheagwam, KS; Adoki, A; Okoro, IC (2005). Remediation of Crude Oil Contaminated Soil by Enhanced Natural Attenuation Technique. J Appl Sci Environ Mgt. 9: 103-105.

Evans, FF; Rosado, AS; Sebastian, GV; Casella, R; Machado, PLOA; Holmstrom, C; Kjelleberg, S; van Elsas JD; Seldin, L (2004) Impact of Oil Contamination and Biostimulation on the Diversity of
Indigenous Bacterial Communities in Soil Microcosms. FEMS Microbiol Ecol. 49: 295-305.

Frick, CM; Farrell, RE; Germida, JJ (1999). Assessment of Phytoremediation as an in-situ Technique for Cleaning Oil-Contaminated Sites. Report submitted to Petroleum Technology Alliance of Canada. Available at https://cluin.org/download/remed/phyassess.pdf. (Accessed on 5th November, 2017).

Hach Company (1992). Hach Water Analysis Handbook. 2nd ed. Loveland, CO. Available at https://www.hach.com/wah. (Accessed on 5th November, 2017).

Hagwell, IS; Delfino, LM; Rao, JJ (1992). Partitioning of Polycyclic Aromatic Hydrocarbons from Oil into Water. Environ. Sci. Technol. 26: 2104-2110.

Hamamura, N; Olson, SH; Ward, DM; Inskeep, WP (2006). Microbial population Dynamics Associated with Crude Oil Biodegradation in Diverse Soils. Appl Environ Microbiol. 72: 6316-6324.

Hobbs, C (1995). Medicinal Mushrooms: Santa Cruz, C. A; Botanica Press, p. 110-5. Available at http://www.acupuncturetoday.com/herbcentral/maitak e.php. (Accessed on 5th November, 2017).

Hornback, JM (1998). Organic Chemistry. Brooks/Cole Publishing, Pacific Grove, CA. Available at https://manyebooks.org/download/organic_chemistry_ hornback 2nd edition_solutions_manual.pdf. (Accessed on 5th November, 2017).

Huesemann, MH; Moore, KO (1993). Compositional Changes during Landfarming of Weathered Michigan Crude oOil-Contaminated Soil. J. Soil Contam. 2:245246.

Idemudia, MI; Osula, AN; Odigie, O (2014). Comparative Assessment of Degradation Potentials of Bacteria and Actinomycetes in Soil Contaminated with Motorcycle Spent Oil. Asian Journal of Science and Technology. 5 (8): 482-487.

Ijah, UJJ; Safiyanu, H; Abioye, OP (2008). Comparative Study of Biodegradation of Crude Oil in Soil Amended with Chicken Droppings and NPK Fertilizer. Science World Journal. 3(2):63-67.

Irwin, RJ; Van-Mouwerik, M; Stevens, L; Seese, MD; Basham, W (1997). Environmental Contaminants Encyclopedia. National Park Service, Water Resources Division, Fort Collins, Colorado. Available at https://www.nature.nps.gov/water/ecencyclopedia/ind ex.cfm. (Accessed on 5th November, 2017).

Ismail, HY; Ijah, UJJ; Riskuwa, ML; Allamin, II (2014). Biodegradation of Spent Engine Oil by Bacteria 
Isolated from the Rhizosphere of Legumes grown in Contaminated Soil. Inter. J. Environ. 3 (2): 63-75.

Joo, H; Ndegwa, P; Shoda, M; Phae, C (2008). Bioremediation of Oil Contaminated Soil Using Candida catenulata and Food Waste. Environ. Pollut. 156: 891-896.

Kaplan, CW; Kitts, CL (2004). Bacterial Succession in a Petroleum Land Treatment Unit. Appl Environ Microbiol. 70: 1777-1786.

Kastner, M (2001). Degradation of Aromatic and Polyaromatic Compounds. In: Biotechnology: The Science and the Business, Harwood Academic Press, Switzerland, p. 274- 304.

Klamann, D (1984). Lubricants and Related Products, Verlag Chemie, Weinheim, Deerfield Beach (Florida) and Basel. Available at https://lib.ugent.be/en/catalog/rug01:000701193. (Accessed on 4th November, 2017).

Kvenvolden, KA (2006). Organic Geochemistry - A retrospective of its first 70 years. Organic Geochemistry 37: $1 . \quad$ doi: 10.1016/j.orggeochem.2005.09.001.

Kvenvolden, KA; Cooper, CK (2003). Natural Seepage of Crude Oil into the Marine Environment. Geo-Marine Letters, 23 (3-4): 140-146.

Kwaspisz, E; Wszelaka, J; Marchut, O; Bielecki, S (2008). The Effect of Nitrate and Ammonium Ions on Kinetics of Diesel Oil Degradation by Gordonia alkanivorans S7. International Biodeterioration and Biodegradation. 61 (3): 214-222.

Leahy, JG; Colwell, RR (1990). Microbial Degradation of Hydrocarbons in the Environment. Microbiol Rev. 54: 305-315.

Lee, K; Tremblay, GH; Levy, EM (1993). Bioremediation Application of Slow Release Fertilizers on Low Energy Shorelines. Proceedings of the 1993 Oil Spill Conference. American Petroleum Institute, Washington D.C., p. 449-454.

Macnaughton, SJ; Stephen, JR; Venosa, AO; Davis, GA; Chang, YJ; White, DC (1999). Microbial Population Changes during Bioremediation of an Experimental Oil Spill. Appl Environ Microbiol. 65: 3566-3574.

Maila, MP; Randima, P; Drønen, K; Cloete, TE (2006). Soil Microbial Communities: Influence of Geographic Location and Hydrocarbon Pollutants. J Soil Biol Biochem. 38:303-310.

Maki, H; Sasaki, T; Haramaya, S (2005). PhotoOxidation of Biodegradable Crude Oil and Toxicity of the Photo-Oxidized Products. Chemosph, 44: 11451151.
Mandri, T; Lin, J (2007). Isolation and Characterization of Engine Oil Degrading Indigenous Microorganisms in Kwazulu-Natal, South Africa. African Journal of Biotechnology, 6 (1): 023-027.

Moneke, A; Nwangwu, V (2011). Studies on the Bio utilization of Some Petroleum Hydrocarbons by Single and Mixed Cultures of some Bacterial Species. African Journal of Microbiology Research. 5(12):1457-1466.

National Research Council (1985). Oil in the Sea: Inputs, Fates, and Effects. National Academy Press, Washington, D.C. Available at https://www.nap.edu/catalog/10388/oil-in-the-sea-iiiinputs-fates-and-effects. (Accessed on 4th November, 2015).

Nilanjana, D; Preethy, C (2011). Microbial Degradation of Petroleum Hydrocarbon Contaminants: An Overview. Biotechnology Research International, vol. 2011, Article ID 941810, 13 pages, 2011. doi:10.4061/2011/941810.

Nweke, CO; Okpokwasili, GC (2004). Effects of Bioremediation Treatments on the Bacterial Populations of Soil at Different Depths. Nig $J$ Microbiol. 18: 363-372.

Obayori, SO; Salam, LB (2010). Degradation of Polycyclic Aromatic Hydrocarbons: Role of Plasmids. Sci Res Ess. 5: 4093-4106.

Odokuma, LO; Dickson, AA (2003). Bioremediation of a Crude Oil-Polluted Tropical Rain Forest Soil. Glob J Environ Sci. 2: 29-40.

Okerentugba, PO; Ezeronye, OU (2003). Petroleum Degrading Potentials of Single and Mixed Microbial Cultures Isolated From Rivers And Refinery Effluents In Nigeria. Afr. J. Biotechnol. 2 (9): 293-295.

Okoh, IA (2003). Biodegradation of Bonny Light Crude Oil in Soil Pits in Nigeria Afr. J. Biotechnol. 2 (5): 104 108.

Olutiola, PO; Famurewa, O; Sonntag, HG (1991). An Introduction to General Microbiology: A Practical Approach. Hygiene-Institut Der Universitat Heidelberg. p. 70-74. ISBN 3-89426-042-4.

Onwurah, INE; Ogugua, VN; Onyike, NB; Ochonogor, AE; Otitoju, OF (2007). Crude Oil Spills in the Environment, Effects and Some Innovative Clean-up Biotechnologies. International Journal of Environmental Research. 1 (4): 307-320.

Prescott, LM; Harley, JP; Klein, DE (2002). Microbiology. Fifth Edition, McGraw Hill Inc., New York. p. 20-38, 96-132, 1012-1018. 
Prince, RC (2002). Biodegradation of Petroleum and other Hydrocarbons. In: Encyclopedia of Environmental Microbiology (g. Bitton, G., ed.) John Wiley, New York, p. 2402-2416.

Prince, RC (2005). The Microbiology of Marine Oil Spill Bioremediation. In: Ollivier B, Magot B, editors. Petroleum Microbiology. Washington, DC: American Society for Microbiology (ASM) Press. p. 317-335.

Pritchard, PH; Costa, CF (1991). Alaska Oil Spill Bioremediation Project Science Advisory Board Draft Report. EPA/600/9-91/046 (a,b), U.S. Environmental Protection Agency, Gulf Breeze, FL.

Rahman, KSM; Banat, IM; Thahira, J (2002). Bioremediation of Gasoline Contaminated with Poultry Litter, Coir Pith and Rhamnolipid Biosurfactant. J. Environ. Quality. 24: 19-28.

Riser-Roberts, E (1998). Remediation of Petroleum Contaminated Soils. CRC Press, Boca Raton, FL.

Rojas-Avelizapa, NG; Roldan-Carrillo, T; ZegarraMartinez, H; Munoz-Colunga, AM; FernandezLinares, LC (2007). A Field Trial for an ex-situ Bioremediation of a Drilling Mud-Polluted Site. Chemosphere. 66: 1595-1600.

Sarkhoh, NA; Ghannoum, MA; Ibrahim, AS; Stretton, RJ; Radwan, SS (1990). Crude Oil and Hydrocarbon Degrading Strains of Rhodococcus: Rhodococcus Strains Isolated from Soil and Marine Environments in Kuwait”. Environ. Pollut. 65: 1-18.

Schwab, AP; Su, J; Wetzel, S; Pekarek, S; Banks, MK (1999). Extraction of Petroleum Hydrocarbons from Soil by Mechanical Shaking. Environ. Sci. Technol. 33:1940-1945.

Siciliano, SD; Germida, JJ; Banks, K; Greer, CW (2003) Changes in Microbial Community Composition and Function during a Polyaromatic Hydrocarbon Phytoremediation Field Trial. Appl Environ Microbiol. 69: 483-489.

Singer, ME; Finnerty, WR (1984). Microbial Metabolism of Straight-Chain and Branched Alkanes. In R. M. Atlas (ed.), Petroleum Microbiology. Macmillan Publishing Co., New York, p. 1-60

Singh, H (2006). Mycoremediation: Fungal Bioremediation. Wiley-Interscience, New York, NY,
USA.

Available

at

https://www.hindawi.com/journals/btri/2011/941810/.

(Accessed on 5th November, 2017).

U.S Congress (1991). Office of Technology Assessment. Bioremediation for Marine Oil Spills- Background Paper. 1991a May. 31p. Available from: U.S. Government Printing Office. Washington DC: OTARP-O-70.

Uba, BO; Ifeanyi, VO (2013). Comparative Study on the rate of Biodegradation of Crude Oil by Bacteria and Fungi isolates. Asian Journal of Science and Technology. 4 (04): 004-007.

Venosa, AD; Kadkkhodayan, M; King, DW; Wrenn, BA; Haines, JR; Herrington, T; Strohmeier, K; Suidan, MT (1993). Testing the Efficacy of Oil Spill Bioremediation Products. Proceedings of the 1993 International Oil Spill Conference. American Petroleum Institute, Washington, D.C. p. 487-493.

Vinas, M; Sabate, J; Espuny, MJ; Solanas, AM (2005). Bacterial Community Dynamics and Polycyclic Aromatic Hydrocarbon Degradation during Bioremediation of Heavily Creosote-Contaminated Soil. Appl Environ Microbiol. 71: 7008-7018.

Williams, CM; Grimes, JL; Mikkelsen, RL (1999). The Use of Poultry Litter as Co-Substrate and Source of Inorganic Nutrients and Microorganisms for the exsitu Biodegradation of Petroleum Compounds. Poult Sci. 78: 956-964.

Wolicka, D; Suszek, A; Borkowski, A; Bielecka, A (2009). Application of Aerobic Microorganisms in Bioremediation in situ of Soil Contaminated by Petroleum Products. Biores Technol. 100: 3221-3227.

Zhu, X; Venosa, AD; Suidan, MT; Lee, K (2001). Guidelines for the Bioremediation of Marine Shorelines and Freshwater Wetlands. Report under a contract with Office of Research and Development, U.S. Environmental Protection Agency. Available at https://www.epa.gov/emergency-response/guidelinesbioremediation-marine-shorelines-and-freshwaterwetlands. (Accessed on 2nd November, 2017).

Zucchi, N; Angiolini, L; Borin, S; Brusetti, L; Dietrich, N; Gigliotti, C; Barbieri, P; Sorlini, C; Daffonchio, D (2003). Response of Bacterial Community during Bioremediation of an Oil-Polluted Soil. J Appl Microbiol. 94: 248-257. 